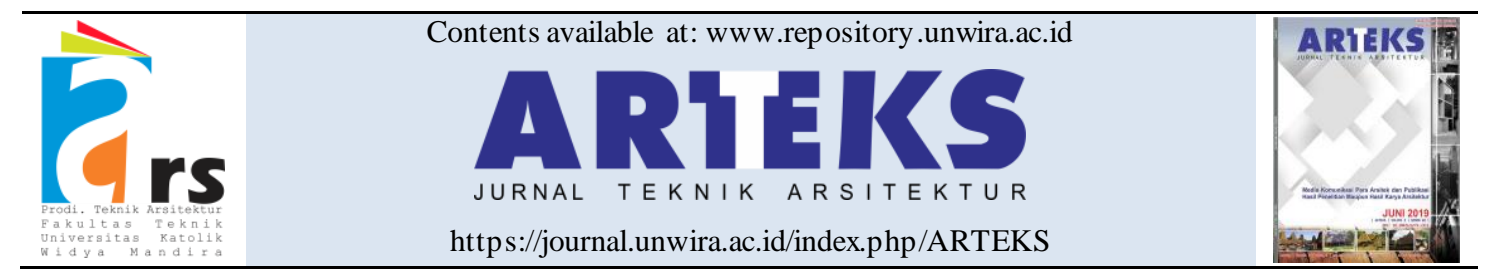

Research paper

doi: 10.30822/arteks.v6i1.565

\title{
The role of outdoor seating facilities for the elderly in dense settlements at Ngampilan Village, Yogyakarta
}

\author{
Diananta Pramitasari* (1), Ulfaizah Sahril, Ahmad Sarwadi \\ Department of Architectural and Planning Engineering, Faculty of Engineering \\ Universitas Gadjah Mada, Jl. Grafika, Kec. Mlati, Sleman, D. I. Yogyakarta, Indonesia
}

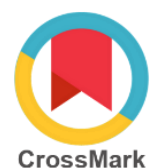

\begin{tabular}{|c|c|}
\hline ARTICLE INFO & ABSTRACT \\
\hline $\begin{array}{l}\text { Article history: } \\
\text { Received June 06, } 2020 \\
\text { Received in revised form August 05, } \\
2020 \\
\text { Accepted September 08, } 2020 \\
\text { Available online April 01, } 2021\end{array}$ & $\begin{array}{l}\text { The environmental amenities of areas with a high elderly population } \\
\text { need to be adjusted to support their lives and ensure they experience } \\
\text { a healthy aging process. Therefore, this research examines the role } \\
\text { of residential areas in providing support to the daily activities of the } \\
\text { elderly for their optimal and everyday use of available outdoor } \\
\text { seating facilities. Data were obtained from } 25 \text { outdoor seating }\end{array}$ \\
\hline $\begin{array}{l}\text { Keywords: } \\
\text { Elderly } \\
\text { Residential environment } \\
\text { Outdoor space } \\
\text { Seating facilities }\end{array}$ & $\begin{array}{l}\text { facilities in a densely populated environment in Yogyakarta City } \\
\text { center through observations, interviews, and person-centered } \\
\text { mapping of the elderly as respondents. The results showed that the } \\
\text { elderly utilize outdoor seating for social, recreation, rest, shelter, } \\
\text { and household activities. Therefore, it is still necessary to improve } \\
\text { the physical quality of seating in these facilities to ensure that they } \\
\text { are maximally utilized by the elderly. The important aspect in } \\
\text { establishing these criteria are as follows: (1) dimensions, (2) }\end{array}$ \\
\hline $\begin{array}{l}\text { *Corresponding author: Diananta } \\
\text { Pramitasari } \\
\text { Department of Architectural and Planning } \\
\text { Engineering, Faculty of Engineering } \\
\text { Universitas Gadjah Mada, Yogyakarta, } \\
\text { Indonesia } \\
\text { Email: dpramitasari@ugm.ac.id } \\
\text { ORCID: https://orcid.org/0000-0002-5640- } \\
0623\end{array}$ & protection, (3) material, (4) Form, and (5) comfort. \\
\hline
\end{tabular}

\section{Introduction}

Indonesia experiences a yearly increase in the elderly population (Sugiharto 2017); . From 1971 - 2017, the country recorded a tremendous increase in the elderly population by $8.97 \%$ or 23 million (Badan Pusat Statistik 2017). The elderly consists of 3 categories, including young 60-69, middle 70-79, and elderly 80+. The Indonesian Ministry of Health (2017) predicted that in the years 2020, 2025, 2030, and 2035 the elderly population is likely to increase by $27.08,33.69$, 40.95, and 48.19 million, respectively (Kementerian Kesehatan RI 2017). According to Priebe \& Howell (2014), the population is expected to reach $33 \%$ of the total population by
2050 (Jan and Howell 2014). Yogyakarta is the province with the most significant elderly percentage of $13.90 \%$ (Badan Pusat Statistik 2017). A 2018 study shows that the city's elderly population is approximately $10 \%$, with a total of 43,426 people (Badan Pusat Statistik Kota Yogyakarta 2018).

The increase in the elderly population is becoming a challenge, especially regarding meeting their quality of life with the majority experiencing physical, mental, and social deterioration (Devi 2016; Misnaniarti 2017). On the otherhand, there are still many elderly people that travel outside their homes with various motivations (Pramitasari and Sarwadi 2015; Srichuae, Nitivattananon, and Perera 2016). 
However, their activities need to be supported by their surrounding environment (Van Holle et al. 2015). For instance, they need to be helped with their various physical activities such as walking comfortably (Gell et al. 2015; Todd et al. 2016; Nyunt et al. 2015; Portegijs et al. 2017). When they are limited to using physical environmental roles for their daily lives, they are potentially inclined to limit their activities. Therefore, the environment or outdoor space needs to consider the physical and psychological needs of the elderly, from a spatial design perspective to facilitate travel, social activities, and other forms of physical participation (Yu 2020). A supportive environment for various activities can improve their quality of life (Curl et al. 2016).

The general environmental factors affecting the level of individual physical activity include aesthetics, accessibility, access to roads and land, transportation safety, recreational facilities, etc (Wang et al. 2016). Furthermore, an influential environmental attribute that encourages the elderly community in participating and mobilizing outside environments include trans portation networks, safety, aes thetics, access to destinations and services, walkable and userfriendly environment, recreational facilities, and pedestrian infrastructure (Murayama et al. 2012; Barnett et al. 2017; Levasseur et al. 2015; Rachele et al. 2019).

Physical activity, such as walking, is strongly associated with pedestrian infrastructure, such as the availability of seating facilities (Rachele et al. 2019). Furthermore, the availability of rest facilities or seating in the environment is a significant need and impetus for them to carry out outdoor activities (Cerin et al. 2013; Cerin et al. 2014; Cerin et al. 2017; Pramitasari and Sarwadi 2015; Sakari et al. 2017). Temelová and Dvor (2012) stated that the desire of the elderly to attend public spaces was due to the availability of sufficient seats (Temelová and Dvořáková 2012). According to Michael et al. (2006), the availability of outdoor seating in a residential area is part of the effort to provide a safe living environment for the elderly to carry out their various activities (Michael, Green, and Farquhar 2006). The World Health Organization (2007) stated that the availability of a seating area for the elderly is necessary in urban and rural areas, due to the difficulty experienced by many while walking around without a guaranteed place to rest (World Health Organization 2007). Therefore, based on this, many outdoor seating facilities are situated in public spaces in the middle of residential areas as part of a resting facility for the elderly.

The descriptions above references show that the subject of elderly dependence on the physical environment has been widely studied. However, the understanding of the relationship between the elderly and their physical environment needs to be achieved to determine suitable criteria. This study aims to examine the role of outdoor seating facilities as part of the elderly's activity space to support their daily life activities. The research emphasizes how the elderly optimally make use of available seating facilities, in order to determine the important and specific criteria. This is considered important because quality environmental facilities encourage social interaction (Bevan and Croucher 2011; Lim et al. 2017). Furthermore, the study on environmental amenities plays a role in increasing the social awareness of the elderly community as one of the vulnerable groups and improves the quality of life towards healthy and active aging.

\section{Method}

\section{Research location}

This research was carried out at Ngampilan Village, Ngampilan Sub-district, the highest density sub-district in Yogyakarta City, consisting of 20,770 people $/ \mathrm{km}^{2}$ and a village with the highest density of 23,177.78 people $/ \mathrm{km}^{2}$ (Badan Pusat Statistik Kota Yogyakarta 2018). The elderly population in Ngampilan sub-district is $13 \%$ or 2,325 people of the total population (Badan Pusat Statistik Kota Yogyakarta 2018). The residential area chosen is Hamlet 07 as shown in figure 1, with the following considerations: (1) the elderly population in Ngampilan Village, is approximately $12.1 \%$ of the total population, (2) the elderly are active and still carry out outdoor activities with various motivations and frequencies (Pramitasari and Sarwadi 2015). 


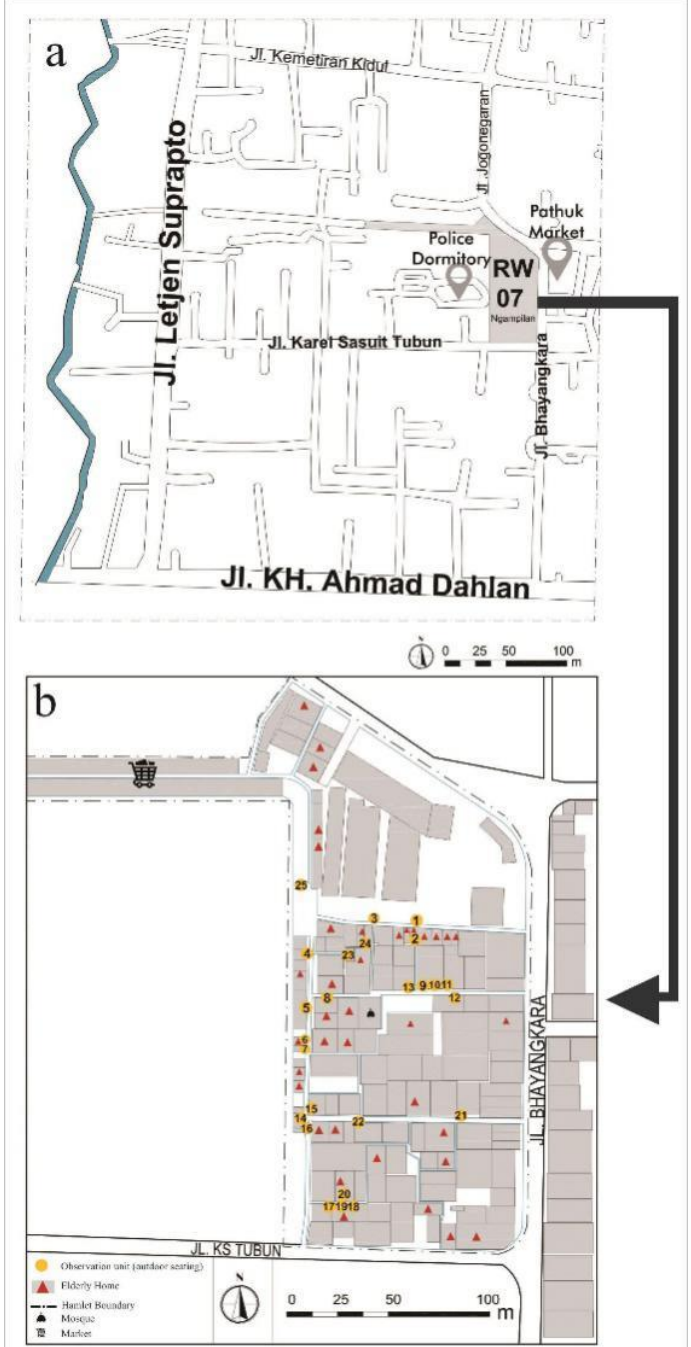

Figure 1. (a) Block plan for Ngampilan Village, (b) Block plan for Hamlet 7 and distribution of 25 observation units \& elderly residences in Hamlet 07

\section{Observation unit}

The observation unit in this research is 25 outdoor seating facilities located in Hamlet 07, Ngampilan Village, with figure $1 \mathrm{~b}$ showing the data distribution location. Figure 2 shows that 25 seats are outside people's houses, located by the roadside, and intended to be used by anyone as a temporary rest area.

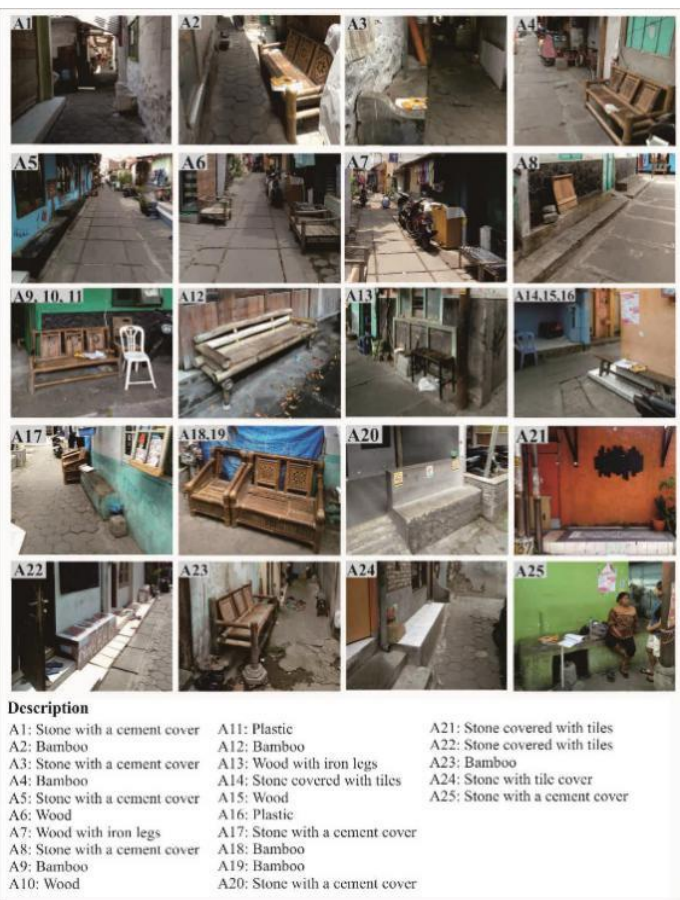

Figure 2. Visual data of 25 observation units in the study area

The seats are observed in physical aspects:(a) forming material, (b) properties (fixed or semifixed), (c) dimensions, (d) shape, (e) location in a residential area, and (f) protection. Meanwhile, the non-physical aspects are focused on the following (a) management systems and (b) user activities. The observed users are divided into 2 , namely the elderly that live in Hamlet 07 environment and those living outside.

Description of the physical condition and management system of the subjects

Observations on 25 subjects were used to record the material, nature, size, shape, location of the area, protection, and management system.

The outdoor seating has various materials, namely: bamboo (7 seats), wood (3), plastic (2), stone covered with cement (7), stone with tile cover (4), and wood with iron legs (2). The seats made of bamboo, wood, plastic, and wood materials had iron legs that are semi-fixed and moveable to nearby locations. Meanwhile, stone seats with cement and tile covers are permanently fixed and cannot be moved.

Data on the shape and design related to the presence or absence of handles (armrests) and backrests, showed that 8 seats had handled as well as backrests (A2, A4, A6, A9, A12, A18, 
A19, A23), 3 had backrests (A10, A11, A16), 11 pieces were against the wall (A1, A3, A5, A7, A8, A13, A17, A20, A22, A24, A25) and none were adjusted on the material used with 3 pieces (A14, A15, A21).

The observed outdoor seating dimensions have average height and length of $25-60 \mathrm{~cm}$ and $20-250 \mathrm{~cm}$, respectively. Sizes of $40-70 \mathrm{~cm}$ can only be used by 1 person and $90-1500 \mathrm{~cm}$ by 2 or more people.

The location of outdoor seating at hamlet 07 environments is divided into two, namely the Rukunan road on the observation units A2, A17, A18, A19, A20, A23, A24, and alley on A1, A3, A4, A5, A6, A7, A8, A9, A10, A11, A12, A13, A14, A15, A16, A21, A22, and A25 as shown in Figure 4.

In terms of protection, most outdoor seating has roofs, although it is not sufficiently protected from heat and rain. The presence of trees also helps as a shade (in A13).

Data regarding the management systemon the provision and maintenance of outdoor seating shows that hamlet, neighborhood, hamlet 07 selfhelp residents, and homeowners (private property) are designated for the public. Overall maintenance is carried out by hamlet, neighborhood, residents through community service, homeowners, and residents that live near these seats.

\section{Research time}

This research was carried out from September to November 2018. The observation time was divided into 3 categories, in accordance with the time mostly used by the elderly for outdoor activities, namely (1) period 1 at 07.00-10.59 (morning), (2) period 2 at 11.00-14.59 (noon), and (3) period 3 at 15.00-17.59 (afternoon). The observation time was based on when the activities of the elderly cross the research area.

\section{Data analysis}

Data from observations, interviews and behavior mapping were qualitatively and descriptively analyzed by categorizing into physical and non-physical. Furthermore, the data were reduced to the analysis unit according to the research location.

\section{Result and discussion}

Use of outdoor seating facilities for the elderly

The research sample consists of 56 elderly between the ages of 60-101 years old. A total of 28 people lives in the research area, while the rest live outside the environment. The results of interviews and observations showed that most outdoor seating is used by the elderly living in the environment. However, only 2 out of the 28 elderly passers took advantage of the existing outdoor seating.

Elderly activities in utilizing outdoor seating facilities

There are 6 categories of activities for the elderly in utilizing outdoor seating, namely (1) social activities such as chatting, meeting friends, greeting passers-by, looking after grandchildren, (2) recreational activities such as watching passers-by and children playing, getting some fresh air, relaxing, reading newspapers, playing cross word puzzles, sunbathing, watching TV, and daydreaming, (3) resting activities, namely taking a break after going to the market, working, carrying out activities at the mosque, eating, sleeping, (4) waiting activities such as waiting for friends to go to the market, hamlet events, laundry arrival, waiting for grandchildren to come home from school, and queues at shops, (5) household activities such as preparing cooking ingredients by cutting vegetables, and (6) taking cover activities during heavy rain and strong winds because they are afraid to be inside the house) as shown in figure 3.

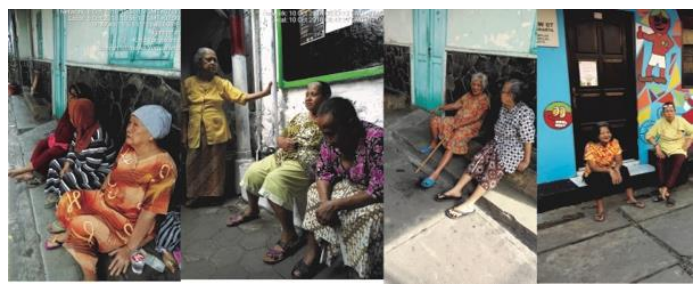

Figure 3. The use of seats by the elderly at Hamlet 07 Ngampilan Village

Figure 3 shows images of the elderly sitting with their relatives, non-elderly residents, and those from outside the neighborhood.

Reasons for the use of outdoor seating facilities by the elderly

The interview shows that there are three reasons as sociated with the use of outdoor seating 
activities by the elderly, namely (1) discomfort in their house, (2) recreation, and (3) the need to rest. The discomfort felt inside the house is because the house is hot, cramped, crowded, and dark. The discomfort is also because of the fear of the elderly of staying indoors during heavy rainfall and strong winds. Their desire for recreation is due to the feeling of boredom, loneliness, and thoughts. Meanwhile, the reason for resting is due to tiredness from walking from the mosque or the market, finishing work, and sitting while looking after their grandchildren.

Time and frequency of elderly using outdoor seating

Observations showed that the time for using outdoor seating by the elderly occurred more in the morning (07.00-10.59) than in the afternoon (11.00-14.59) and evening (14.59-17.59), as shown in graph 1. Meanwhile, based on the interviews' results on the frequency of use, most elderly stated "uncertain", then "every day in morning time", as shown in graph 2.

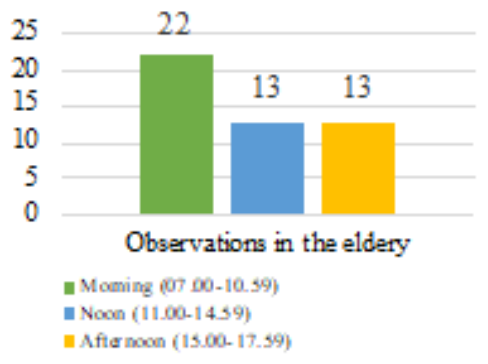

Graph 1. Time of using outdoor seating by the elderly

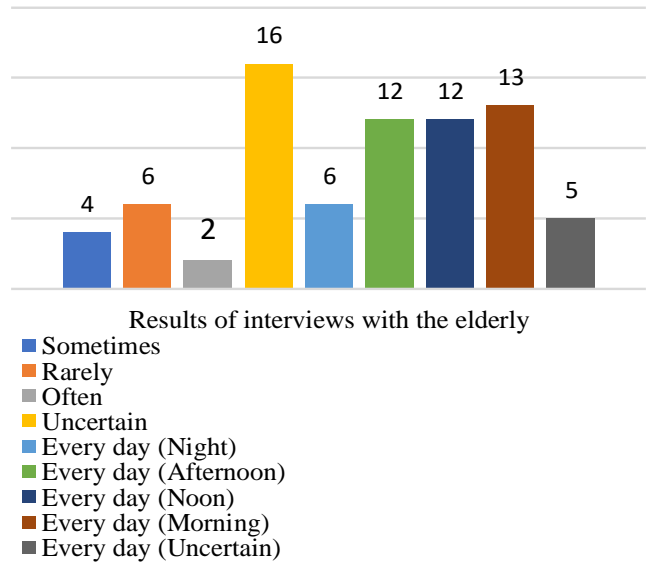

Graph 2. The frequency of using outdoor seating by the elderly
Outdoor seating used by the elderly

The various activities and reasons for utilization showed that outdoor seating plays a significant role in accommodating the elderly's needs. Some seats were used while others were not. The thirteen (13) outdoor seating facilities used by the elderly are A1, A2, A4, A5, A6, A7, A8, A13, A14, A15, A16, A21, and A23, while the rest where unused.

Table 1. The causes of the elderly using the 13 Outdoor seating

\begin{tabular}{|c|c|}
\hline & Aspect \\
\hline Location & $\begin{array}{ll}\text { - } & \text { Near points of activity for people } \\
\text { in the village } \\
\text { - } & \text { Near work } \\
\text { - } & \text { Near home } \\
\text { - } & \text { Near sellers } \\
\text { - } & \text { Lear a relative's house } \\
\text { passer (alley) } \\
\text { - } \\
\text { Passed by the elderly when } \\
\text { carrying out activities outside the } \\
\text { house. }\end{array}$ \\
\hline Protector & $\begin{array}{ll}- & \text { There is a roof for protection } \\
\text { - } & \text { Some trees act as protectors }\end{array}$ \\
\hline $\begin{array}{l}\text { Dimensio } \\
\mathrm{ns}\end{array}$ & $\begin{array}{l}\text { It is spacious; therefore, users } \\
\text { can stretch their legs and sleep }\end{array}$ \\
\hline Material & $\begin{array}{ll}- & \text { Material with tile coverfeels } \\
\text { cooler. }\end{array}$ \\
\hline Others & $\begin{array}{ll}\text { - } & \text { Cool (lots of wind) } \\
\text { - } & \text { Crowds of people } \\
\text { - } & \text { Seated relatives } \\
\text { - } & \text { Feeling bored in a seat that is } \\
\text { always used, therefore the } \\
\text { elderly look for another } \\
\text { - } \quad \text { There is a TV } \\
\text { - } \quad \text { During the day, a seat that is } \\
\text { always used is hot, therefore } \\
\text { they tend to look for another. } \\
\text { After the rain, the seat that is } \\
\text { always used is wet, therefore } \\
\text { they tend to look for another. }\end{array}$ \\
\hline
\end{tabular}

Table 1 shows several aspects that underlie the decision to use chairs by the elderly. The management systemrelated to the seat provider is not related to the utilization decision. This is because the elderly feel they have a kinship with the residents even though the seats are private property placed by the roadside.

Out of the 13 seats, A1, A5, A8, A14, A15, were mostly used as shown in Figure 4. Table 2 shows that the location aspect is the main criterion for them to choose seats. The first is the proximity of the seats as well as activity points in the 
environment. This is followed by the seat's location on a strategic road, such as the main route. This location is in accordance with the elderly wishes to have social and recreational activities because it enables them to interact with other people while carrying out outdoor activities. Several other aspects were also found, namely coolness and the presence of relatives that were also sitting.

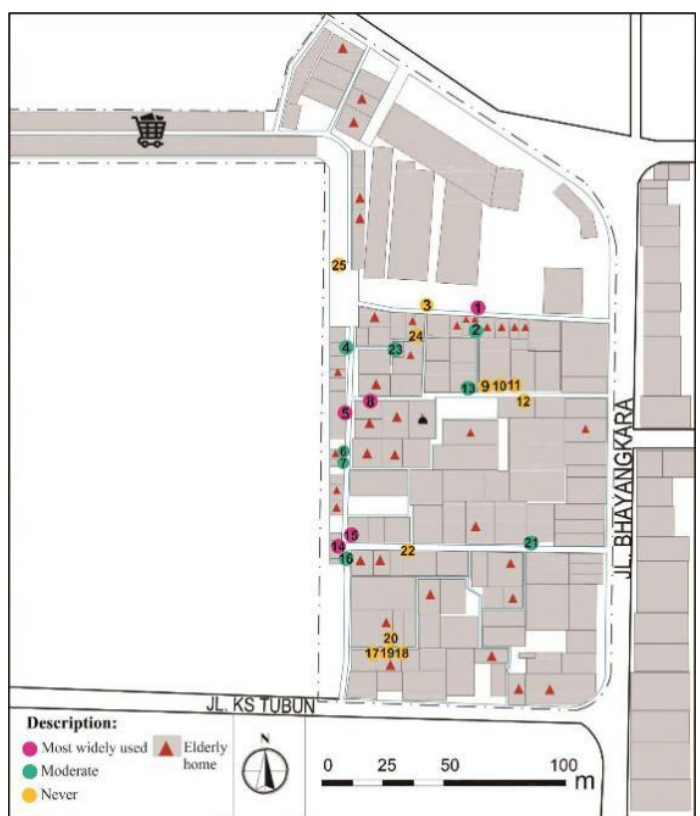

Figure 4. Seat categories used by the elderly and the home distribution

Table 2. The cause of outdoor seat is mostly used by the elderly

\begin{tabular}{|c|c|c|c|c|c|c|c|c|c|c|c|c|c|c|c|c|c|}
\hline \multirow{2}{*}{$\begin{array}{l}\text { Observation } \\
\text { Unit (subject) }\end{array}$} & \multicolumn{17}{|c|}{ Aspect } \\
\hline & $\mathrm{a}$ & $\mathrm{b}$ & $\mathrm{c}$ & $\mathrm{d}$ & $\mathrm{e}$ & $\mathrm{f}$ & $\mathrm{g}$ & $\mathrm{h}$ & $\mathrm{i}$ & $\mathrm{j}$ & $\mathrm{k}$ & 1 & $\mathrm{~m}$ & $\mathrm{n}$ & $\bar{o}$ & $\mathrm{p}$ & $\mathrm{q}$ \\
\hline$\overline{\mathrm{A} 1}$ & $\bullet$ & $\bullet$ & $\bullet$ & 0 & $\mathrm{o}$ & $\mathrm{o}$ & 0 & $\mathrm{o}$ & $\mathrm{O}$ & 0 & 0 & $\bullet$ & $\bullet$ & $\mathrm{o}$ & 0 & 0 & 0 \\
\hline A5 & $\bullet$ & $\bullet$ & $\bullet$ & $\bullet$ & $\bullet$ & $\circ$ & o & $\bullet$ & $\mathrm{o}$ & o & $\circ$ & $\bullet$ & $\bullet$ & - & 0 & 0 & 0 \\
\hline A8 & $\bullet$ & $\bullet$ & $\bullet$ & $\bullet$ & $\bullet$ & $\circ$ & $\mathrm{o}$ & 0 & $\mathrm{o}$ & 0 & $\circ$ & $\bullet$ & $\bullet$ & - & $\bullet$ & 0 & 0 \\
\hline A14 & $\bullet$ & $\bullet$ & $\bullet$ & $\bullet$ & $\bullet$ & $\bullet$ & 0 & 0 & $\bullet$ & $\bullet$ & $\bullet$ & $\bullet$ & $\bullet$ & - & 0 & $\bullet$ & $\bullet$ \\
\hline $\mathrm{A} 15$ & $\bullet$ & $\bullet$ & $\bullet$ & $\circ$ & $\bullet$ & $\bullet$ & $\bullet$ & $\circ$ & $\circ$ & $\circ$ & $\circ$ & $\bullet$ & $\bullet$ & o & o & $\bullet$ & o \\
\hline \multicolumn{18}{|l|}{ Description: } \\
\hline \multicolumn{8}{|l|}{ Location aspect } & \multicolumn{10}{|c|}{ Mate rial Aspects } \\
\hline \multirow{3}{*}{\multicolumn{8}{|c|}{$\begin{array}{l}\text { a. Near home. } \\
\text { b. Located on a strategic route traversed by passers-by. } \\
\text { c. Passed by the elderly when carrying out activities } \\
\text { outside the home. }\end{array}$}} & \multirow{2}{*}{\multicolumn{10}{|c|}{ j. Material with a ceramic cover feels cooler. }} \\
\hline & & & & & & & & & & \multicolumn{5}{|c|}{ Dimension Aspects } & & & \\
\hline & & & & & & & & & $\begin{array}{l}\text { A size } \\
\text { the le }\end{array}$ & 420 & 25( & & & & & & \\
\hline \multicolumn{8}{|c|}{ d. Near the points where people sell. } & \multicolumn{10}{|c|}{ Other Aspects } \\
\hline \multirow{2}{*}{\multicolumn{8}{|c|}{$\begin{array}{l}\text { e. Near to the activity point of people in the village. } \\
\text { f. Near to therelative's house. }\end{array}$}} & \multirow{2}{*}{\multicolumn{10}{|c|}{$\begin{array}{l}\text { 1. Relatives are sitting in that place. } \\
\text { m. Cool (lots of wind). }\end{array}$}} \\
\hline & & & & & & & & & & & & & & & & & \\
\hline \multicolumn{8}{|l|}{ g. Near work. } & \multicolumn{10}{|c|}{$\begin{array}{l}\text { n. A family is sitting in that place. } \\
\text { o. There is a morning sun. }\end{array}$} \\
\hline \multicolumn{8}{|c|}{ Protective Aspects } & \multicolumn{10}{|c|}{ p. Gathered crowds of people. } \\
\hline \multicolumn{8}{|c|}{ h. Protected from the hot afternoon sun. } & \multicolumn{10}{|c|}{ q. L } \\
\hline
\end{tabular}

The seats provided by Hamlet is A5, Neighborhood is A14, A16, and A21, while nongovernmental organizations are A1, A3, and A25. The benefit of A 3 and A25 are not maximized by the elderly despite being in a strategic lane with A9, A10, A11, A12, and A25 as shown in figure 4. This means that seats that are not close to the elderly's house are not utilized. Similarly, when the seat is near the elderly's house and in a strategic route as A3, without a roof, it is not utilized. The same thing is seen in A22, where other seats such as A14 and A15 are more utilized due to their large size, closeness to TV facilities, and as a place for residents to gather.

Furthermore, when the seats are close to the elderly's house, such as A2 in figure 4, but not on a strategic road, they are not used. This is because the elderly prefers seats on strategic roads such as A1 in figure 4 , to have an adequate view of passers-by.

The elderly also looks for protected seats that are not too far from their home, close to relatives' 
houses, and places used for various activities. This shows that they need seats located close to their home and in strategic locations, with support from other aspects, namely, dimensions and protection.

Problems faced by the elderly when using a seat

Several problems are encountered by the elderly in aspects of (1) dimensions, (2) protection, (3) material, and (4) form/design, as shown in Table 3.

The elderly are seen seated in residential areas on a daily basis therefore, these places need to be comfortable for them irrespective of the time. The physical condition of the seat, especially the dimensions, is an important aspect to support their activities. The data shows that a seat with dimensions of $152 \mathrm{~cm}$ length is not sufficient to be used by more than 3 people. A seat height of $60 \mathrm{~cm}$ is considered too high, while those that are $25 \mathrm{~cm}$ is too short. According to the elderly, the right height is $30-40 \mathrm{~cm}$, while the use of stone materials with cement covers is easy to moss. Plastic materials are not sturdy, and bamboo materials are not resistant. Another aspect mentioned is the protective aspect, namely the absence of a roof to sufficiently protect them from the sun and rain.

Table 3. Problems faced by the elderly when using a seat

\begin{tabular}{ll}
\hline Aspect & \multicolumn{1}{c}{ Problems } \\
\hline Dimension \\
\hline A1 & $\begin{array}{l}\text { A length of } 152 \mathrm{~cm} \text { is not enough to } \\
\text { accommodate more than } 3 \text { people. Therefore, } \\
\text { the elderly claimed that they sit on their } \\
\text { neighbor's house terrace to enable other } \\
\text { relatives to join them. }\end{array}$ \\
\hline A5 & The seat is too short by $25 \mathrm{~cm}$. \\
\hline A13 & The seat is too high by $60 \mathrm{~cm}$. \\
\hline Protector & $\begin{array}{l}\text { The roof only protects part of the seat from the } \\
\text { afternoon sun (in this case, themorning sun is } \\
\text { not a problem) and rain. Therefore, when the } \\
\text { seats get wet, they look for other places to sit. }\end{array}$ \\
\hline A4, A5, & $\begin{array}{l}\text { The roof does not protect them from the } \\
\text { morning sun (in this case, the afternoon sun is } \\
\text { not a problem). Therefore, the elderly prefers } \\
\text { not to when they are not exposed to the hot } \\
\text { morning sun. }\end{array}$ \\
\hline A15 & $\begin{array}{l}\text { There is no roof, therefore they often move to } \\
\text { places with protected coverage. }\end{array}$ \\
\hline A 6 & $\begin{array}{l}\text { There is no roof, therefore the seats are not } \\
\text { protected from the hot sun. }\end{array}$ \\
\hline Material & $\begin{array}{l}\text { Stone material with a cement cover is easily } \\
\text { mossy after being exposed to rain. }\end{array}$ \\
\hline A1 & $\begin{array}{l}\text { Bamboo material does not last for a certain } \\
\text { period. }\end{array}$ \\
\hline A4 &
\end{tabular}

\begin{tabular}{lc}
\hline Aspect & \multicolumn{1}{c}{ Problems } \\
\hline A16 & Plastic material is not sturdy or easy to shake. \\
\hline Form & \\
\hline A15 & There is no backrest on the seat. \\
\hline
\end{tabular}

As previously mentioned, the problem of dimensions, protection, and material are the categories widely used by the elderly to carry out their sitting patterns. There are two things involved in the design and formation of the availability of a backrest and a handle (armrests). However, some elderly people admit that they need chair handles due to their ability to help them easily stand up.

The elderly needs their seat to be located in strategic locations that are physically and psychologically comfortable. Furthermore, the area needs to be cool, with relatives or families sitting and the presence of a TV to encourage them to keep using the existing seat. Strategic points close to the elderly's house, which also provides a visual of the crowd or passing people, can attract a crowd. A residential environment that able to fulfill the elderly needs in their activities provides them with the opportunity to move and have activities around their house. This is because the situation tends to stimulate activities for the elderly further. This is in line with several previous studies, which stated that the existence of seating facilities in the elderly's living environment tends to complement environmental amenities. This stimulates the elderly to move outside the home and mobilize in their residential environment (Rosso et al. 2013). Other research results showed that a good living environment produces a strong foundation of security for the elderly (Katz et al. 2011).

This research, which was carried out in Ngampilan Village, showed that despite sufficient outdoor seating, when the facility does not provide visual access to crowds and places of passing people, the seating becomes underutilized.

\section{Conclusion}

This research explains that outdoor seating facilities are part of the daily living space used by the elderly to accommodate social activities, recreation, rest, shelter, and household activities. The seats' physical condition tends to influence the elderly's decision to support their activities. Locations near their homes are important because 
many activity points are carried out in the neighborhood and on strategic roads traversed by many people. Therefore, it is important to improve the seat physical quality in order to achieve the criteria for facilities used by the elderly maximally. The important aspects in establishing these criteria are (1) dimensions: the seats need to have a width that can be used by more than 3 people and a height of $30-40 \mathrm{~cm}$, (2) protection: the seats need to be protected from sunlight and rain, (3) materials: stones with ceramic covers need to be used to build the seats, (4) form: It needs to have a backrest, and (5) comfort: it needs to be situated in a cool, and crowded place with relatives that support amenities.

\section{References}

Badan Pusat Statistik. 2017. Statistik Penduduk Lanjut Usia 2017. Jakarta: Badan Pusat Statistik.

https://www.bps.go.id/publication/2018/04/1 3/7a130a22aa29cc8219c5d153/statis tikpenduduk-lanjut-usia-2017.html.

Badan Pusat Statistik Kota Yogyakarta. 2018. Kecamatan Ngampilan Dalam Angka. Yogyakarta: Badan Pusat Statistik Kota Yogyakarta.

Barnett, David W., Anthony Barnett, Andrea Nathan, Jelle Van Cauwenberg, and Ester Cerin. 2017. 'Built Environmental Correlates of Older Adults' Total Physical Activity and Walking: A Systematic Review and MetaAnalysis'. International Journal of Behavioral Nutrition and Physical Activity 14 (1): 103. https://doi.org/10.1186/s 12966-0 17 0558-z.

Bevan, Mark, and Karen Croucher. 2011. Lifetime Neighbourhoods. London: Department for Communities and Local Government. https://as sets.publishing.service.gov.uk/gover nment/uploads/system/uploads/attachment_d ata/file/6248/2044122.pdf.

Cerin, Ester, Andrea Nathan, Jelle van Cauwenberg, David W. Barnett, and Anthony Barnett. 2017. 'The Neighbourhood Physical Environment and Active Travel in Older Adults: A Systematic Review and MetaAnalysis'. International Journal of Behavioral Nutrition and Physical Activity 14
(1): 15. https://doi.org/10.1186/s 12966-0170471-5.

Cerin, Ester, Cindy H. P. Sit, Anthony Barnett, Man-chin Cheung, and Wai-man Chan. 2013. 'Walking for Recreation and Perceptions of the Neighborhood Environment in Older Chinese Urban Dwellers'. Journal of Urban Health $\quad 90 \quad$ (1): 56-66. https://doi.org/10.1007/s 11524-012-9704-8.

Cerin, Ester, Cindy HP Sit, Anthony Barnett, Janice M Johnston, Man-Chin Cheung, and Wai-Man Chan. 2014. 'Ageing in an UltraDense Metropolis: Perceived Neighbourhood Characteristics and Utilitarian Walking in Hong Kong Elders'. Public Health Nutrition 17 (1): 225-32. https://doi.org/10.1017/S1368980012003862.

Curl, Angela, Catharine Ward Thompson, Susana Alves, and Peter Aspinall. 2016. 'Outdoor Environmental Supportiveness and Older People's Quality of Life: A Personal Projects Approach'. Journal of Housing For the Elderly $\quad 30 \quad$ (1): $\quad 1-17$. https://doi.org/10.1080/02763893.2015.1087 925.

Devi, Evian. 2016. 'Pola Penataan Ruang Panti Jompo Berdasarkan Aktivitas Dan Perilaku Penghuninya'. ARTEKS: Jurnal Teknik Arsitektur 1 (1): $131-48$. https://doi.org/10.30822/arteks.v 1i1.24.

Gell, Nancy M., Dori E. Rosenberg, Jordan Carlson, Jacqueline Kerr, and Basia Belza. 2015. 'Built Environment Attributes Related to GPS Measured Active Trips in Mid-Life and Older Adults with Mobility Disabilities'. Disability and Health Journal 8 (2): 290-95. https://doi.org/10.1016/j.dhjo.2014.12.002.

Holle, Veerle Van, Jelle Van Cauwenberg, Benedicte Deforche, Nico Van de Weghe, Ilse De Bourdeaudhuij, and Delfien Van Dyck. 2015. 'Do PsychosocialFactors Moderate the Association between Objective Neighborhood Walkability and Older Adults' Physical Activity?' Health \& Place 34 (July): 118-25. https://doi.org/10.1016/j.healthplace.2015.05. 004.

Jan, Priebe, and Fiona Howell. 2014. 'Old-Age Poverty in Indonesia: Empirical Evidence and Policy Options A Role for Social Pensions'. Jakarta. http://www.tnp2k.go.id/downloads/oldagepoverty-in-indonesia-empirical-evidence- 
and-policy-options-a-role-for-social-

pensions.

Katz, Jeanne, Caroline Holland, Sheila Peace, and Emily Taylor. 2011. 'A Better Life: What Older People with High Support Needs Value'. York. https://oro.open.ac.uk/30290/1/older-peopleand-high-support-needs-summary.pdf.

Kementerian Kesehatan RI. 2017. 'Analis is Lansia Di Indonesia'. Jakarta.

Levasseur, Mélanie, Mélissa Généreux, JeanFrançois Bruneau, Alain Vanasse, Éric Chabot, Claude Beaulac, and Marie-Michèle Bédard. 2015. 'Importance of Proximity to Resources, Social Support, Transportation and Neighborhood Security for Mobility and Social Participation in Older Adults: Results from a Scoping Study'. BMC Public Health 15 (1): 503. https://doi.org/10.1186/s 12889-0151824-0.

Lim, Tricia Su Ying, Norhaslina Hassan, Amirhosein Ghaffarianhoseini, and Md Nasir Daud. 2017. 'The Relationship between Satisfaction towards Neighbourhood Facilities and Social Trust in Urban Villages in Kuala Lumpur'. Cities 67 (July): 85-94. https://doi.org/10.1016/j.cities.2017.04.006.

Michael, Yvonne L., Mandy K. Green, and Stephanie A. Farquhar. 2006. 'Neighborhood Design and Active Aging'. Health \& Place 12 (4): 734-40. https://doi.org/10.1016/j.healthplace.2005.08. 002.

Misnaniarti. 2017. 'Analis is Situasi Penduduk Lanjut Usia Dan Upaya Peningkatan Kesejahteraan Sosial Di Indonesia'. Jurnal Ilmu Kesehatan Masyarakat 8 (2): 67-73. https://doi.org/https://doi.org/10.26553/jikm. 2016.8.2.67-73.

Murayama, Hiroshi, Satoru Yoshie, Ikuko Sugawara, Tomoko Wakui, and Reiko Arami. 2012. 'Contextual Effect of Neighborhood Environment on Homebound Elderly in a Japanese Community'. Archives of Gerontology and Geriatrics 54 (1): 67-71. https://doi.org/10.1016/j.archger.201 1.03.016

Nyunt, Ma Shwe Zin, Faysal Kabir Shuvo, Jia Yen Eng, Keng Bee Yap, Samuel Scherer, Li Min Hee, Siew Pang Chan, and Tze Pin Ng. 2015. 'Objective and Subjective Measures of Neighborhood Environment (NE): Relationships with Transportation Physical Activity among Older Persons'. International
Journal of Behavioral Nutrition and Physical $\begin{array}{llll}\text { Activity } & 12 & \text { (1): } & 108 .\end{array}$ https://doi.org/10.1186/s 12966-015-0276-3.

Portegijs, Erja, Kirsi Keskinen, Li-Tang Tsai, Taina Rantanen, and Merja Rantakokko. 2017. 'Physical Limitations, Walkability, Perceived Environmental Facilitators and Physical Activity of Older Adults in Finland'. International Journal of Environmental Research and Public Health 14 (3): 333. https://doi.org/10.3390/ijerph14030333.

Pramitasari, Diananta, and Ahmad Sarwadi. 2015. 'A Study on Elderly's Going Out Activities and Environment Facilities'. Procedia Environmental Sciences 28: 315-23. https://doi.org/10.1016/j.proenv.2015.07.040.

Rachele, Jerome N., Takemi Sugiyama, Sasha Davies, Venurs H.Y. Loh, Gavin Turrell, Alison Carver, and Ester Cerin. 2019. 'Neighbourhood Built Environment and Physical Function among Mid-to-Older Aged Adults: A Systematic Review'. Health \& Place $\quad 58 \quad$ (July): 102137. https://doi.org/10.1016/j.healthplace.2019.05. 015 .

Rosso, Andrea L., Tony H. Grubesic, Amy H. Auchincloss, Loni P. Tabb, and Yvonne L. Michael. 2013. 'Neighborhood Amenities and Mobility in Older Adults'. American Journal of Epidemiology 178 (5): 761-69. https://doi.org/10.1093/aje/kwt032.

Sakari, Ritva, Merja Rantakokko, Erja Portegijs, Susanne Iwarsson, Sarianna Sipilä, Anne Viljanen, and Taina Rantanen. 2017. 'Do Associations Between Perceived Environmental and Individual Characteristics and Walking Limitations Depend on Lower Extremity Performance Level?' Journal of Aging and Health 29 (4): 640-56. https://doi.org/10.1177/0898264316641081.

Srichuae, Sariya, Vilas Nitivattananon, and Ranjith Perera. 2016. 'Aging Society in Bangkok and the Factors Affecting Mobility of Elderly in Urban Public Spaces and Transportation Facilities'. IATSS Research 40 (1): 26-34. https://doi.org/10.1016/j.iatss r.2015.12.004.

Sugiharto, Adriana. 2017. 'Perancangan Bangunan Hunian Lansia Berdasarkan Aksesibilitas Penghuni Pada Lingkungan Dan Bangunan'. ARTEKS: Jurnal Teknik 
Arsitektur $1 \quad$ (2): $\quad 99-116$. https://doi.org/10.30822/arteks.v1i2.31.

Temelová, Jana, and Nina Dvořáková. 2012. 'Residential Satis faction of Elderly in the City Centre: The Case of Revitalizing Neighbourhoods in Prague'. Cities 29 (5): 310-17. https://doi.org/10.1016/j.cities.2011.11.015.

Todd, Michael, Marc A. Adams, Jonathan Kurka, Terry L. Conway, Kelli L. Cain, Matthew P. Buman, Lawrence D. Frank, James F. Sallis, and Abby C. King. 2016. 'GIS-Measured Walkability, Transit, and Recreation Environments in Relation to Older Adults' Physical Activity: A Latent Profile Analysis'. Preventive Medicine 93 (December): 57-63. https://doi.org/10.1016/j.ypmed.2016.09.019.

Van Holle, V., Van Cauwenberg, J., Deforche, B., Van de Weghe, N., De Bourdeaudhuij, I., \& Van Dyck, D. (2015). Do psychosocial factors moderate the association between objective neighborhood walkability and older adults' physical activity? Health \& Place, 34, 118-
125. https://doi.org/10.1016/j.healthplace.2015.05. 004.

Wang, Y., C.K. Chau, W.Y. Ng, and T.M. Leung. 2016. 'A Review on the Effects of Physical Built Environment Attributes on Enhancing Walking and Cycling Activity Levels within Residential Neighborhoods'. Cities 50 (February): 1-15. https://doi.org/10.1016/j.cities.2015.08.004.

World Health Organization. 2007. Global AgeFriendly Cities: A Guide. France: World Health Organization. https://www.who.int/ageing/publications/Glo bal_age_friendly_cities_Guide_English.pdf.

Yu, Qin. 2020. 'Outdoor Space Analys is and Thinking in Old Urban Residential Area Under the Goal of Healthy Settlements'. In Proceedings of the 5th International Conference on Social Sciences and Economic Development (ICSSED 2020). Paris, France: Atlantis Press. https://doi.org/10.2991/as sehr.k.200331.102. 